International Journal of Language Education

Volume 5, Number 3, 2021, pp. 180-192

ISSN: $2548-8457$ (Print) 2548-8465 (Online)

Doi: https://doi.org/10.26858/ijole.v5i3.18350

\title{
Critical Thinking in Second Language Learning: Students' Attitudes and Beliefs
}

\author{
Malikhatul Lailiyah \\ Universitas Merdeka Malang, Indonesia \\ Email: malikhatul.lailiyah@unmer.ac.id \\ Prilla Lukis Wediyantoro \\ Universitas Merdeka Malang, Indonesia \\ Email: prillawediyantoro@unmer.ac.id
}

Received: 10 January 2021

Reviewed: 1 June 2021-29 September 2021

Accepted: 1 October 2021

\begin{abstract}
Researches revealed that critical thinking is a solely appraised learning outcome in higher education. However, the study related to students' perceptions of critical thinking in online learning is not greatly expanded. This study explored students' attitudes and beliefs of critical thinking within asynchronous learning environments. The participants of this study were English as a Foreign Language (EFL) students in one of the universities in Malang. To gain deep understanding, both quantitative and qualitative approach was applied. In obtaining the data, a set of questionnaires was distributed through google form and analyzed to describe the learners' perception. Besides, to draw supplementary information, a form of deep interviews with six students was conducted. The findings indicated that even though the analysis of the questionnaire showed students' positive attitudes toward critical thinking skills, however, from the interview section, it is showed that students' were lack of confidence. In addition, there was multifaced understanding what critical thinking are.
\end{abstract}

Keywords: critical thinking; English language learning; students' perception; thinking skills

\section{Introduction}

One of the crucial issues in higher education is developing students' critical thinking (CT). While some researchers believe that CT is naturally processed by everyone; not necessary to be taught at school, others contend that the goals of education is to promote the students' ability in thinking especially CT skills (e.g. Alazzi, 2008; Gelder, 2005). Despite the fact that students have the ability to think naturally, it is essential to provide teaching experience that leads the students to think critically (Asgharheidari \& Tahriri, 2015; Choy \& Cheah, 2009; Mandernach et al., 2009; Patel, 2013), such as encourage students to ask thought-provoking questions (Gul et al., 2014) or using various teaching materials explicitly (Halpern, 1999).

Research in educational context proofed that teachers have to prepare students for their successful lives; thus, they have to develop the students' CT skills. Be that as it may, it is important for educators to have strategies in helping students to develop and to apply CT in solving their 
academic problems (Živkovil, 2016). In language learning, researchers agree that the role of a teacher in developing students' CT skills is decisive (Asgharheidari \& Tahriri, 2015). Thus, it is necessary to set the goal in their class: promoting CT skills while learning the target language.

Despite the fact that $\mathrm{CT}$ is essential, teachers should provide teaching strategies that promote students' CT skills. Many studies mentioned the use of strategies in developing ones' CT skills in a classroom context. Narmaditya et al. (2017) investigated the use of problem-based learning. The result revealed that using this strategy is effective in enhancing students' CT skills. In line with this, Redhana (2013) studied the science students' performance through using of problem-based learning and Socratic questions. The result reported that these strategies were effective in increasing students' CT skills.

Critical thinking has been included in Indonesian education systems, yet the implementation in the teaching and learning process is very limited. The possible reasons why educators in Indonesia do not apply critical thinking for their classroom activities is they may not understand how to be critical and how to promote critical thinking skills (As'ari et al., 2017; Djiwandono, 2013; Ilyas, 2017). Therefore, to develop critical thinking in students, teachers have to prepare themselves as critical thinkers.

Previously, many studies have been conducted in relation to the correlation of CT with other aspects, such as the positive correlation of CT on higher education students' academic performance (see D'Alessio et al., 2019; Ghazivakili et al., 2014) and the correlation of CT and students' self-leadership (e.g. Ay et al., 2015; Flores et al., 2012; Jenkins \& Cutchens, 2011). Research on investigating individuals perception on CT in educational setting, such as teachers' perception (e.g. Alazzi, 2008; Cassum et al., 2013), faculties' perception (e.g. Twibell et al., 2005), and students' perception (Tapper*, 2004), is not something new. However, studies claimed that it is necessary for educators to delve into their learners' perceptions on learning to knowing how they perceived their perception (Choy \& Cheah, 2009). In addition, Huber \& Kuncel (2016) reported in their study that there is a lack of studies in investigating students' actual understanding of the term CT and whether they are capable of performing accurate self-asssesments.

In recognizing above mentioned gap in the literature and exploring on data from survey and interviews, this study intended to examine students' perceptions of CT. Taking Indonesian English as a Foreign Learning (EFL) students as an example, this present study tries to contribute to the study of CT on EFL learners. Recently, there are a lot of problems caused by the lack of ones' critical thinking; it is proven from how easily someone is provoked by unproven information. No doubt that the improvement of Indonesian students' CT skills should be taken into account. Henceforth, the application of CT in Indonesia is of prime importance to be studied since there are only very limited studies related to this field in the Indonesian education system. For that reason, ELT teachers are deemed as the key role to enhance critical thinking abilities in language learners. In this connection, the present study aims to:

1. to investigate the EFL students' attitudes and beliefs of CT skills.

2. to investigate the perceptions of EFL students towards the confidence, valuing, and misconceptions of $\mathrm{CT}$ in their higher education.

\section{Research method}

Students' attitudes and beliefs toward CT skills were investigated using both qualitative and quantitative methods. In what follows, the participants, data collections, and data analysis procedures are elucidated. 


\section{Participants}

The participants were 38 sophomore EFL students enrolling in a Diploma education program who took Intermediate Reading class at a university in Malang, Indonesia. These participants were chosen for they were the students the researchers taught when the study was carried out. Meanwhile, Intermediate Reading class is a course that designed to provide activities on analyzing of various academic reading texts. The goal of this course is to develop students' critical thinking skills through crafting drafts on a writing assignment of comparative analysis, argument, and exploratory synthesis.

The survey was distributed to 45 students in two classes. A brief overview of the objective of data collection is provided so that students could understand the underlying purposes of the questionnaire and research. All the participants voluntarily participated to complete an online survey. A total of 38 valid answers were collected, this accounts for an $84.4 \%$ response rate of the total number of students. Among them, $76.3 \%$ were female $(\mathrm{N}=29)$ and $23.7 \%$ were male $(\mathrm{N}=$ $9)$, who ranged in age from 19 to 25 years $(\mathrm{M}=21.36, \mathrm{SD}=1.4)$. The summarized of demographic information is presented in Table 1.

Table 1. Demographic Information of Participants

\begin{tabular}{cll}
\hline Attributes & F & $\%$ \\
\hline Gender & 9 & \\
Male & 29 & 23.7 \\
Female & & 76.3 \\
Age & 2 & \\
19 & 8 & 5.3 \\
20 & 15 & 21 \\
21 & 4 & 39.5 \\
22 & 6 & 10.5 \\
23 & 2 & 15.8 \\
24 & 1 & 5.3 \\
25 & 2.6 \\
\hline
\end{tabular}

Meanwhile, semi-structured interviews with a sample of 6 participants were done regarding their perception of CT skills. The participants were chosen purposively. A purposive sample is considered to be acceptable to provide maximum insight (Ary et al., 2018). In electing the interviewee, the elements of gender and age were taken into consideration. Table 2 presents the participants' profiles. The anonym was used to protect participants' personal information.

Table 2. Interviewee Profile

\begin{tabular}{ccc}
\hline Participants & Gender & Age \\
\hline A & Female & 20 \\
B & Male & 21 \\
C & Male & 21 \\
\hline
\end{tabular}




\begin{tabular}{lll}
\hline D & Female & 20 \\
E & Female & 20 \\
F & Female & 20 \\
\hline
\end{tabular}

Data collections

In order to explore the participants' attitudes and beliefs toward CT skills, the main instrument was adapted from the Critical Thinking Toolkit (CriTT) questionnaire developed by Stupple et al. (2017). This questionnaire is chosen since the questionnaire can be used in an educational setting to explore not only students' perception about CT but also to help students understand the benefit and the concept of CT.

The CriTT measures students' attitudes and beliefs in three major components: confidence in $\mathrm{CT}$, valuing $\mathrm{CT}$, and misconceptions. It is a 27 -item questionnaire that measures $\mathrm{CT}$ based on the 10-point Likert scale (ranging from 1 strongly disagree to 10 strongly agree). Most of the questions are the same as those developed by Stupple et al. (2017), except that the current study omitted 1 question "Factor Confidence in CT - When designing experiments I can readily eliminate extraneous variables". This question was discarded as a result of the pilot study because most of the participants did not understand this question. The distribution of items is presented in Figure 1 .

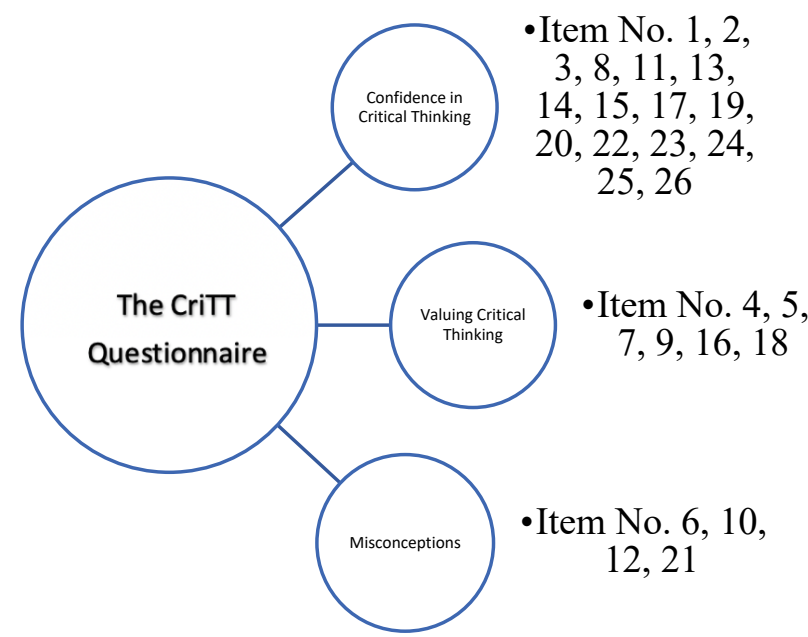

Figure 1. The Critical Thinking Toolkit (CriTT) questionnaire based on Stupple et al.'s (2017) study

In the qualitative approach, semi-structured interviews were conducted to get an in-depth insight into students' perception of CT skills. The process of interview was conducted after the analysis of the survey. The interviews were conducted through telephone and were recorded, and then transcribed.

Data analysis

The data collected through Google Forms were analysed using SPSS to provide a descriptive analysis of the questionnaire. In this research, Means and Standard Deviations are reported to depict the students' perceptions about CT.

In the qualitative phase, the first author transcribed and uploaded the data of the interview to NVivo 12 Software. Then, the transcripts, which were guided by keywords, analysed 
thematically as suggested by Braun and Clarke (2006). The results and interpretations were drawn from the data and then reviewed by the second member of the research team to provide broad discussion regarding the findings.

\section{Findings}

Analysis of CriTT questionnaire

The main goal of this study was to delve into higher education students of EFL learners' attitudes and beliefs toward CT skills. The main instrument used was the attitudes and beliefs questionnaire based on Stupple et al.'s (2017) study. Table 3 shows the means, standard deviations, and the proportions for the twenty-six items in the questionnaire.

The respondents reported their highest positive attitudes towards item Valuing critical thinking/ VCT2 that stated their agreement of CT is essential in higher education $(\mathrm{M}=8.82)$. On the other hand, the lowest mean, $\mathrm{M}=6.03$, was item Confidence in critical thinking/ CCT3 that clarified students' ability in identifying the structure of arguments without being distracted by their content. In spite of that, the participants' responses were found to be heterogeneous in terms of their attitudes toward their ability in identifying analogies between theories (CCT13 SD = 1.97). On the contrary, the responses were homogeneous with respect to item CCT9 that probed students' viewpoint toward their understanding on how to approach complex issues in many ways ( $\mathrm{SD}=$ 1.11).

Table 3. Mean, Standard Deviation, and The Proportion of Students on Each Scale

\begin{tabular}{|c|c|c|c|c|c|c|c|}
\hline \multirow[t]{2}{*}{ Attributes } & \multirow[t]{2}{*}{ Items } & \multirow[t]{2}{*}{ Mean } & \multirow{2}{*}{$\begin{array}{l}\text { Standard } \\
\text { Deviation }\end{array}$} & \multicolumn{2}{|c|}{ Agreed } & \multicolumn{2}{|c|}{ Disagreed } \\
\hline & & & & $\mathrm{F}$ & $\%$ & $\mathrm{~F}$ & $\%$ \\
\hline Factor 1: & CCT1 & 6.97 & 1.51 & 31 & 81.58 & 7 & 18.4 \\
\hline Confidence in & ССТ2 & 7.66 & 1.61 & 35 & 92.11 & 3 & 7.9 \\
\hline Critical & ССТ3 & 6.03 & 1.69 & 24 & 63.16 & 14 & 36.8 \\
\hline \multirow{13}{*}{ Thinking } & CCT4 & 7.42 & 1.58 & 33 & 86.84 & 5 & 13.2 \\
\hline & CCT5 & 7.32 & 1.57 & 33 & 86.84 & 5 & 13.2 \\
\hline & ССТ6 & 6.97 & 1.51 & 31 & 81.58 & 5 & 13.2 \\
\hline & СCT7 & 7.24 & 1.68 & 33 & 86.84 & 5 & 13.2 \\
\hline & ССТ8 & 7.55 & 1.63 & 34 & 89.47 & 4 & 10.5 \\
\hline & ССТ9 & 6.84 & 1.11 & 33 & 86.84 & 5 & 13.2 \\
\hline & CCT10 & 7.47 & 1.33 & 36 & 94.74 & 2 & 5.3 \\
\hline & CCT11 & 7.61 & 1.33 & 36 & 94.74 & 2 & 5.3 \\
\hline & CCT12 & 6.92 & 1.53 & 31 & 81.58 & 7 & 18.4 \\
\hline & CCT13 & 6.97 & 1.97 & 31 & 81.58 & 7 & 18.4 \\
\hline & CCT14 & 7.42 & 1.58 & 34 & 89.47 & 4 & 10.5 \\
\hline & CCT15 & 7.37 & 1.55 & 32 & 84.21 & 6 & 15.8 \\
\hline & CCT16 & 7.18 & 1.83 & 33 & 86.84 & 5 & 13.2 \\
\hline Factor 2: & VCT1 & 8.47 & 1.37 & 37 & 97.37 & 1 & 2.63 \\
\hline Valuing & VCT2 & 8.82 & 1.12 & 38 & 100.00 & 0 & 0.00 \\
\hline Critical & VCT3 & 7.55 & 1.71 & 33 & 86.84 & 5 & 13.16 \\
\hline \multirow[t]{3}{*}{ Thinking } & VCT4 & 6.86 & 1.95 & 28 & 73.68 & 9 & 23.68 \\
\hline & VCT5 & 8.03 & 1.58 & 34 & 89.47 & 4 & 10.53 \\
\hline & VCT6 & 7.37 & 1.71 & 34 & 89.47 & 4 & 10.53 \\
\hline Factor 3: & MCT1 & 7.58 & 1.74 & 35 & 92.11 & 3 & 7.89 \\
\hline \multirow{3}{*}{ Misconceptions } & MCT2 & 7.18 & 1.85 & 31 & 81.58 & 7 & 18.42 \\
\hline & MCT3 & 7.21 & 1.95 & 31 & 81.58 & 7 & 18.42 \\
\hline & MCT4 & 7.45 & 1.92 & 33 & 86.84 & 5 & 13.16 \\
\hline
\end{tabular}


The following section will discuss the details of each factor in the questionnaire. In the statistics result for Factor 1 "Confidence in Critical Thinking", generally, participants agreed that they were confident with their CT skills. Item CCT10 and CCT11, with 36 of the total respondents or $94.74 \%$, were the highest agreement among others. This indicates that most of the students believed that they had the ability to judge the value of new information or evidence presented to them and to evaluate others' arguments well. On the other hand, only 24 students were able to identify the structure of arguments without being distracted by their content (Item CCT3). This was equal to $63.16 \%$. Meanwhile, based on the data presented, Factor 2: valuing CT concerned the students' attitudes toward the importance of CT skills in higher education, participants displayed a reasonably strong collective agreement that $\mathrm{CT}$ is essential for their education. To add more, item VCT2 revealed that all participants confirmed that CT skills are essential for higher education. The data also revealed participants' considerable agreement that they consciously believed that their CT skills is developing through their higher education study (VCT3 $M=7.55$ ). Finally, the statistics result for Factor 3 "Misconceptions" showed that participants demonstrated a strong understanding of the concept of CT. It indicates that the participants do not have misconceptions about the concept and the implementation of CT.

Analysis of the students' interviews

The interview data were transcribed, uploaded to NVivo 12 Software, and then analyzed by using three main keywords: confidence, valuing, and misconception on CT skills. The details of each attribute will be presented below.

\section{Confidence in $C T$}

Confidence in CT was perceived by participants as their own tenet about their confidence in CT. Among all the participants, $66.7 \%$ or 4 students, were unsured whether they are good critical thinkers or not (see Figure 2). They expressed their own belief about their reason when they are asked whether they are critical thinkers or not:

"I think, I am a curious person because I need a detailed information in some topic that I interest with" (Participant A).

Participant A believed that being a critical thinker means probing many questions and should not received any information blindly. And she claimed that she is an inquisitive person who tends to find the information she is interested in. However, she responded to the question of whether she identified herself as critical thinkers or not with an unsure answer. She continued:

"Even so, sometimes other people easily controlled me. And it bothers me, how easily I influenced by others" (Participant A).

Clearly, from her response, Participant A in this study was perceived as lacking of confidence. While another students, Participant B, expressed his perspective:

"I always think pros and cons or positive and negative about something, also I can accept and understand the actual meaning of sarcastic or satire without getting offended." 
He pointed out that he is open-minded, has diverse perspectives, and logical person. However, in responding to the question "Do you think that you are a critical thinker?" Participant B responded it with "Maybe. I don't know". Similarly, Participants C and F also have the same responses. They claimed that they are always analyse and evaluate any information they received before making any judgement. However, the said that they have no idea whether they are critical thinkers or not. In contrast, the two other students: Participant D and E, without any hesitation, claimed that they are critical thinkers. One student claimed that she has independent viewpoints when she processing information:

"The simplest example is during the lecture question and answer session. The question I have posed is no longer about what the definition is but rather about what happens if ' $\mathrm{A}$ ' affects ' $\mathrm{B}$ ', why 'A' could have such an impact on 'B', how can 'B' be affected by 'A' and so on. In the organization, I also apply the same thing in making plan $\mathrm{A}, \mathrm{B}, \mathrm{C}$ in rundown for minimizing the worst possibility occurrence"

(Participant E).

Participant E believed that she can generate diverse perspectives in questioning a problem. She also mentioned that she has self-disciplined thinking. Participant E's response is proved that she sufficiently confident in CT.

To sum up, from the interviews, more than half of the participants were unsure whether they are critical thinker or not. They are also mentioned how they are easily provoked. This is can be used to verify that they are lack of confidence of their CT skills.

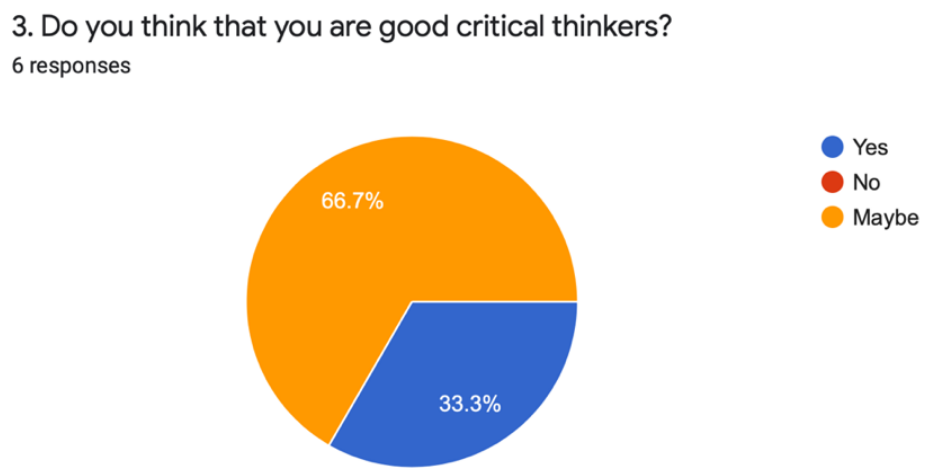

Figure 2. Responses from the questions no. 3

\section{Valuing $C T$}

This part tried to figure out to what extent students understand the importance of CT. In the interview section, all of the participants agreed that critical thinking is essential for their degree. One participant described the importance of $\mathrm{CT}$ and associated this with the fundamental of having CT skills in the digital era:

"Because, in this modern era it is a must to think critically for all of those aspect in our life. Because with that too, we can maintain ourself in every adaptational condition." (Participant F) 
Others were aware that CT is essential for solving a problem that they faced, as one of the statement:

"Well, critical thinking helps me to dealing with a problem, I do ask meaningful questions, consider alternative points of view, apply logic and reason, avoid assumptions and consider all opportunities. And that behavior really helps me whether in education or daily life." (Participant C)

Participants believed that CT was also valued and described as one of the fundamental skills in education:

"Because in higher education, in a college, being critical thinker is essential to show our competence. Every student has the same chance to study in the same textbook, in the same room, got the same knowledge but the difference of each student is how they can think in a critical way." (Participant D)

To that end, valuing CT skills was influential concern that need to be recognized. This is because valuing CT is connected to the participation's perception of why they need CT skill. Thus, it might associate with the development of CT skills when they valued it.

\section{Misconceptions}

This section measures whether there was or there was not the participants' misinterpretation about CT skills. The participants were asked to complete a statement: "A critical thinker is a person who..." Then, participants' statements were coded, and the results are as follow:

The term "ability in analyzing" was mentioned three times. Participant D, for example, stated that "(critical thinker) has an intelligent ability to think or analyze something in a complex subject." The variation of this term included "ability in analyzing objectively" (Participant F) and "think sharply and deeply" (Participant E)

Another term mentioned by the students was "having logical and reasonable thinking" which appeared three times. For instance, Participant A mentioned "(critical thinker) has ability to think logically to solve the problem based on the real information." Other than that, Participant C stated that a critical thinker is someone who "has the skill to make logical decisions, based on information obtained". And Participant B in his comment also mentioned "thinks clearly and rationally" as one of the characteristics of a critical thinker.

In addition, they also mentioned "truth-seeking". Participant F stated that “... it involves the evaluation of sources, such as data, facts, observable phenomena, and research findings." Finally, one student also brought "open-minded" as the characteristic of a critical thinker. Participant B mentioned, "...to understand both sides either pros and cons or positive and negative of a subject."

Misconceptions emphasized the participants' understanding of CT skills. From the interview, it is believed that participants' perspective related to CT skills is multifaceted responses. The deeper analysis will be explained on discussion section.

\section{Discussion}

Returning to the research objective of this study, in answering the first objective, descriptive statistics were used to obtain respondents' perceived level of CT skills. The finding 
indicated that a great majority of the participants had positive attitudes toward CT skills for all the factors. Analysis of the data revealed that most of the students who participated in the study had valued the importance of CT in their degree. Researchers have already acknowledged the link between students' positive attitudes and their language learning success (such as Kormos \& Csizér, 2008; Yang, 2012). Further, strong responses to the factor items valuing the CT skills were the collective tendency to agree that students did have a clear understanding of the importance of CT skills. However, among the 3 factors, the level of students' confidence in CT is the lowest one. Moreover, in the interview result, students tend to question their own CT ability. This can be the result of their lack of confidence.

Many studies mentioned the absence of CT skills in the school curriculum is the factor in contributing to students' lack of these skills (Stapleton, 2011). Nonetheless, Adeyemi (2012) emphasised that the quality of people produce and build highly depends on what they think. Therefore, no doubt that the fundamental of developing students' CT skills cannot be neglected. In line with the participants' responses regarding their belief that CT skills are essential in this modern era; the research found that instruction in critical thinking is prior to learning since it can improve students' understanding of the information they find, and cultivates better judgment in their real-life (Dwyer et al., 2014). Hence, it is important for each individual to have habits of CT. There is a lot of information provided by digital technology that requires one to think about it logically, not just simply accept everything they hear or see. This skill can be taught and developed through many strategies as proposed in many studies.

A plethora research studies investigating various kinds of teaching strategies that promoting students' CT ability in both traditional and online classroom setting (e.g. Alwehaibi, 2012; Jones, 2017; Popil, 2011; Seibert, 2021; Smith et al., 2018; Vacek, 2009). For instance, Marquez (2017) discussed how to teach CT efficiently by using teaching strategies that allowed students to raise questions and engage in meaningful discussions. In online learning setting, it requires a learning design that enhances participants' interaction to achieve students' learning experience and outcomes (Kusumawati, 2020). To bring this issue, Wediyantoro et al. (2020) proposed to use Socratic Questions to engage students' CT on classroom discussions especially in an online classroom. The result showed that there was a positive effect on students' depth of CT skills. This indicates that the method can be used as one of the alternative classroom activities to promote students' CT skills in an online learning environment.

In addition, these findings provide further support of the previous research about students' attitudes and beliefs and the importance of fostering higher education students' CT skills in order to prepare them for their future careers. Zhang et al. (2020), for instance, investigated higher education EFL teachers' perception of CT in China through a series of Likert-style and open-ended questionnaires to find teachers' beliefs about $\mathrm{CT}$ and what they know about it. Besides, they also interviewed 12 teachers to get deeper teachers' perceptions about $\mathrm{CT}$ and its teaching. The result revealed that EFL teachers in China believed that CT should be applied in the EFL curriculum. Nevertheless, the result showed that teachers lacked the understanding of CT and how to implement it in the classroom.

Despite the fact that in survey section, participants had a clear perception about the meaning of $\mathrm{CT}$, however, deeper analysis on interview section, their notion tends to be mixt understanding with the CT disposition. Other assumptions were CT skills have multiple definitions. This result was in line with Stapleton's (2011) study that revealed the various participants' responses lead to the fact that participants had divergent meanings of CT. To add more, studies also mentioned that eventhough participants agree that CT is important, however they seem lack of consensus on its 
definition (Cassum et al. (2013). This might happen because participants have interpreted based on their own understanding (Alazzi, 2008).

\section{Conclusion}

The present study explored students' attitudes and beliefs toward CT skills. There were 3 factors that were identified, namely confidence in CT, valuing CT, and misconception. In general, the result of the survey showed that students showed positive attitudes toward confidence in their CT, and valuing CT sufficiently. Besides, there were no students' misconception of CT. However, the finding from the interview demonstrated that each participant proposed a different meaning of $\mathrm{CT}$, thus it can be assumed that there was a misunderstanding related to CT meaning. To add more, even the analysis of the result of the questionnaire showed that students' have confidence in CT, however, in the interview section, participants tend to lack of confidence.

This present study broadened the EFL students' attitudes and beliefs toward CT skills. However, since the perception of a small number of Indonesian EFL learners is explored, the result cannot be generalized to the larger context. Therefore, it is necessary to conduct similar research with a larger sample in the same disciplines. Future research might also compare between students' perceptions and the level of CT skills.

Declaration of conflicting interest

The authors state that there is no conflict of interest concerning the publication of this paper.

Funding acknowledgement

The researchers would like to thank University of Merdeka Malang for funding this research project under the UNMER Research Grant 2020 Scheme.

\section{References}

Adeyemi, S. B. (2012). Developing critical thinking skills in students: a mandate for higher education in Nigeria. European Journal of Educational Research, 1(2), 155-161. https://doi.org/https://doi.org/10.12973/eu-jer.1.2.155

Alazzi, K. F. (2008). Teachers' perceptions of critical thinking: A study of Jordanian secondary school social studies teachers. The Social Studies, 99(6), 243-248. https://doi.org/https://doi.org/10.3200/TSSS.99.6.243-248

Alwehaibi, H. U. (2012). Novel program to promote critical thinking among higher education students: Empirical study from Saudi Arabia. Asian Social Science, 8(11), 193. https://doi.org/doi:10.5539/ass.v8n11p193

Ary, D., Jacobs, L. C., Irvine, C. K. S., \& Walker, D. (2018). Introduction to research in education. Cengage Learning.

As'ari, A. R., Mahmudi, A., \& Nuerlaelah, E. (2017). Our prospective mathematic teachers are not critical thinkers yet. Journal on Mathematics Education. https://doi.org/10.22342/jme.8.2.3961.145-156

Asgharheidari, F., \& Tahriri, A. (2015). A survey of EFL teachers' attitudes towards critical thinking instruction. Journal of Language Teaching and Research, 6(2), 388-396. https://doi.org/10.17507/jltr.0602.20

Ay, F. A., Karakaya, A., \& Yilmaz, K. (2015). Relations between self-leadership and critical thinking skills. Procedia - Social and Behavioral Sciences, 207(2015), 29-41. https://doi.org/10.1016/j.sbspro.2015.10.147 
Braun, V., \& Clarke, V. (2006). Using thematic analysis in psychology. Qualitative Research in Psychology, 3(2), 77-101. https://doi.org/https://doi.org/10.1191/1478088706qp063oa

Cassum, S. H., McGrath, J. P., Gul, R. B., Dilshad, A., \& Syeda, K. (2013). Multidimensionality of critical thinking: A holistic perspective from multidisciplinary educators in Karachi, Pakistan. Journal of Nursing Education and Practice, 3(7), 9.

Choy, S. C., \& Cheah, P. K. (2009). Teacher perceptions of critical thinking among students and its influence on higher education. International Journal of Teaching and Learning in Higher Education, 20(2), 198-206.

D’Alessio, F. A., Avolio, B. E., \& Charles, V. (2019). Studying the impact of critical thinking on the academic performance of executive MBA students. Thinking Skills and Creativity, 31(2019), 275-283. https://doi.org/10.1016/j.tsc.2019.02.002

Djiwandono, P. I. (2013). Critical thinking skills for language students. Teflin Journal, 24(1), 3247. https://doi.org/10.2307/3471579

Dwyer, C. P., Hogan, M. J., \& Stewart, I. (2014). An integrated critical thinking framework for the $21 \mathrm{st}$ century. Thinking Skills and Creativity, 12, 43-52. https://doi.org/10.1016/j.tsc.2013.12.004

Flores, K. L., Matkin, G. S., Burbach, M. E., Quinn, C. E., \& Harding, H. (2012). Deficient critical thinking skills among college graduates: Implications for leadership. Educational Philosophy and Theory, 44(2), 212-230. https://doi.org/doi: 10.1111/j.14695812.2010.00672.x

Gelder, T. Van. (2005). Teaching critical thinking: Some lessons from cognitive science. College Teaching, 53(1), 41-48. https://doi.org/10.1063/1.3047631

Ghazivakili, Z., Norouzi Nia, R., Panahi, F., Karimi, M., Gholsorkhi, H., \& Ahmadi, Z. (2014). The role of critical thinking skills and learning styles of university students in their academic performance. Journal of Advances in Medical Education \& Professionalism, 2(3), 95-102. http://www.ncbi.nlm.nih.gov/pubmed/25512928\%0Ahttp://www.pubmedcentral.nih.gov/ar ticlerender.fcgi?artid=PMC4235550

Gul, R. B., Khan, S., Ahmed, A., Cassum, S., Saeed, T., Parpio, Y., \& Profetto-mcgrath, J. (2014). Enhancing educators' skills for promoting critical thinking in their classroom discourses : A randomized control trial. International Journal of Teaching and Learning in Higher Education, 26(1), 37-54. http://www.isetl.org/ijtlhe/

Huber, C. R., \& Kuncel, N. R. (2016). Does college teach critical thinking? A meta-analysis. Review of Educational Research, 86(2), 431-468. https://doi.org/https://doi.org/10.3102\%2F0034654315605917

Ilyas, H. P. (2017). Historical perspective: The development of critical thinking in Indonesian ELT. Journal of ELT Research. https://doi.org/10.22236/jer_vol2issue2pp89-102

Jenkins, D. M., \& Cutchens, A. B. (2011). Leading critically: A grounded theory of applied critical thinking in leadership studies. Journal of Leadership Education, 10(2), 1-21.

Jones, T. (2017). Playing detective to enhance critical thinking. Teaching and Learning in Nursing, 12(1). https://doi.org/10.1016/j.teln.2016.09.005

Kormos, J., \& Csizér, K. (2008). Age-related differences in the motivation of learning English as a Foreign Language Universidad de Guayaquil. Language Learning, 58(2), 327-355.

Kusumawati, A. J. (2020). Redesigning face-to-face into online learning for speaking competence during COVID-19: ESP for higher education in Indonesia. International Journal of Language Education, 4(2), 276. https://doi.org/10.26858/ijole.v4i2.14745

Mandernach, B. J., Forrest, K. D., Babutzke, J. L., \& Manker, L. R. (2009). The role of instructor 
interactivity in promoting critical thinking in online and face-to-face classrooms. MERLOT Journal of Online Learning and Teaching, 5(1), 49-62.

Marquez, L. P. (2017). Critical thinking in philippine education: What we have and what we need. Journal for Critical Education Policy Studies, 15(2), 272-303.

Narmaditya, B. S., Wulandari, D., \& Sakarji, S. R. B. (2018). Does problem-based learning improve critical thinking skill? Jurnal Cakrawala Pendidikan, 37(3).

Patel, D. M. (2013). Effectiveness of critical thinking programme on students of class IX in relation to gender. International Journal for Research in Education, 2(7), 16-19.

Popil, I. (2011). Promotion of critical thinking by using case studies as teaching method. Nurse Education Today, 31(2), 204-207. https://doi.org/https://doi.org/10.1016/j.nedt.2010.06.002

Redhana, I. W. (2013). Model pembelajaran berbasis masalah dan pertanyaan socratik untuk meningkatkan keterampilan berpikir kritis siswa. Jurnal Cakrawala Pendidikan, 3, 351-365. https://doi.org/10.21831/cp.v0i3.1136

Seibert, S. A. (2021). Problem-based learning: A strategy to foster generation Z's critical thinking and perseverance. Teaching and Learning in Nursing, 16(1), 85-88. https://doi.org/https://doi.org/10.1016/j.teln.2020.09.002

Smith, T. E., Rama, P. S., \& Helms, J. R. (2018). Teaching critical thinking in a GE class: A flipped model. Thinking Skills and Creativity, 28. https://doi.org/10.1016/j.tsc.2018.02.010

Stapleton, P. (2011). A survey of attitudes towards critical thinking among Hong Kong secondary school teachers: Implications for policy change. Thinking Skills and Creativity, 6(2011), 1423. https://doi.org/10.1016/j.tsc.2010.11.002

Stupple, E. J. N., Maratos, F. A., Elander, J., Hunt, T. E., Cheung, K. Y. F., \& Aubeeluck, A. V. (2017). Development of the Critical Thinking Toolkit (CriTT): A measure of student attitudes and beliefs about critical thinking. Thinking Skills and Creativity, 23, 91-100. https://doi.org/10.1016/j.tsc.2016.11.007

Tapper*, J. (2004). Student perceptions of how critical thinking is embedded in a degree program. Higher Education Research \& Development, 23(2), 199-222. https://doi.org/https://doi.org/10.1080/0729436042000206663

Twibell, R., Ryan, M., \& Hermiz, M. (2005). Faculty perceptions of critical thinking in student clinical experiences. Journal of Nursing Education, 44(2), 71-79. https://doi.org/https://doi.org/10.3928/01484834-20050201-06

Vacek, J. E. (2009). Using a conceptual approach with concept mapping to promote critical thinking. Journal of Nursing Education, 48(1), 45-48. https://doi.org/https://doi.org/10.3928/01484834-20090101-11

Wediyantoro, P. L., Lailiyah, M., \& Yustisia, K. K. (2020). Synchronous discussion in online learning: Investigating students ' critical thinking. EnJourMe (English Journal of Merdeka) : Culture, Language, and Teaching of English, 5(2), 196-203. https://doi.org/10.26905/enjourme.v5i2.5205

Yang, X. (2012). Attitude and motivation in L2 learning among UM master students. International Journal of Management and Sustainability, $1(1), \quad 13-22$. https://doi.org/10.18488/journal.11/2012.1.1/11.1.13.22

Zhang, H., Yuan, R., \& He, X. (2020). Investigating university EFL teachers' perceptions of critical thinking and its teaching: voices from China. Asia-Pacific Education Researcher. https://doi.org/10.1007/s40299-020-00500-6

Živkovil, S. (2016). A model of critical thinking as an important attribute for success in the 21st 
century. Procedia - Social and Behavioral Sciences, 232(April), 102-108. https://doi.org/10.1016/j.sbspro.2016.10.034. 